\title{
HUBUNGAN PERILAKU SEDENTARI DENGAN SINDROM METABOLIK PADA PEKERJA
}

\author{
Lailiyah Yusna Yusfita \\ Puskesmas Pakis, Kota Surabaya \\ Alamat korespondensi: Lailiyah Yusna Yusfita \\ E-mail: Lailiyahyusfita@yahoo.co.id
}

\begin{abstract}
Sedentary lifestyle has been done by many workers either in the workplace, home, even on transportation. High sedentary lifestyle is a risk factor for metabolic syndrome among workers that cause of metabolic diseases such as Coronary Heart Disease, diabetes mellitus type 2, and Stroke. According to the International Diabetes Federation (IDF) in 2005, the metabolic syndrome is characterized by abdominal obesity plus at least 2 other positive components consisting of hypertriglycerides, low HDL cholesterol, hypertension, and hyperglycemia. This study is a cross sectional study to determine relationship of sedentary lifestyle with metabolic syndrome. 66 workers of 113 workers who performed Medical Check Up (MCU) at Prima Medika Laboratory Surabaya during November - December 2017 became a sample of this study. Sampling method was simple random sampling. The independent variables in this study were age, sex, and sedentary lifestyle. The dependent variable was metabolic syndrome. This study used Chi-square analysis to assess the relationship between independent variable and dependent variable. The results showed the prevalence of metabolic syndrome among workers was 43.9\%. Of the 29 workers with metabolic syndrome, 26 workers had a sedentary lifestyle $\geq 6$ hours per day with a median was 9.11 hours per day. There was a correlation between sedentary lifestyle $\geq 6$ hours per day with metabolic syndrome $(p=0.000)$, whereas showed no association with metabolic syndrome between age $(p=$ $0.058)$ and $\operatorname{sex}(p=0.168)$. The conclusions of this study were sedentary $\geq 6$ hours per day associated with metabolic syndrome among workers. Workers should reduce sedentary lifestyle by stretching, avoiding sitting too long while working, and increasing physical activity in the workplace.
\end{abstract}

Keywords: abdominal obesity, worker, sedentary behavior, metabolic syndrome

\begin{abstract}
ABSTRAK
Perilaku sedentari banyak dilakukan oleh pekerja baik di tempat kerja, di rumah, bahkan di perjalanan atau transportasi. Tingginya perilaku sedentari menjadi faktor risiko sindrom metabolik pada pekerja yang merupakan salah satu penyebab penyakit metabolik seperti Penyakit Jantung Koroner (PJK), diabetes melitus tipe 2, dan Stroke. Berdasarkan International Diabetes Federation (IDF) tahun 2005 sindrom metabolik ditandai dengan adanya obesitas sentral ditambah minimal 2 komponen positif lain yang terdiri dari hipertrigliserida, kolesterol HDL rendah, hipertensi, dan hiperglikemia. Penelitian ini merupakan studi cross sectional. Sampel pada penelitian ini adalah 66 pekerja dari total populasi sebanyak 113 pekerja yang melakukan Medical Check Up (MCU) di Laboratorium Prima Medika Surabaya pada Bulan November - Desember 2017. Pengambilan sampel dilakukan dengan cara simple random sampling. Variabel bebas dalam penelitian ini meliputi usia, jenis kelamin, dan perilaku sedentari. Variabel terikatnya adalah sindrom metabolik. Penelitian ini menggunakan analisis Chisquare untuk menilai hubungan antara variabel independen dan variabel dependen. Hasil penelitian menunjukkan prevalensi sindrom metabolik pada pekerja sebesar 43,9\%. Dari 29 pekerja yang mengalami sindrom metabolik, sebanyak 26 pekerja memiliki perilaku sedentari kurang dari 6 jam per hari dengan rata-rata perilaku sedentari 9, 11 jam per hari. Terdapat hubungan antara perilaku sedentari dengan sindrom metabolik $(p$ $=0,000)$, sedangkan antara usia $(p=0,058)$ dan jenis kelamin $(p=0,168)$ menunjukkan tidak ada hubungan dengan sindrom metabolik. Kesimpulan dari penelitian ini adalah perilaku sedentari lebih dari sama dengan 6 jam/ hari berhubungan dengan sindrom metabolik pada pekerja. Pekerja hendaknya mengurangi perilaku sedentari dengan melakukan peregangan, menghindari duduk terlalu lama saat bekerja, dan memperbanyak aktivitas fisik di tempat kerja.
\end{abstract}

Kata kunci : obesitas sentral, pekerja, perilaku sedentari, sindrom metabolic 


\section{PENDAHULUAN}

Penyakit Tidak menular (PTM) merupakan penyakit kronis yang tidak menular, memiliki durasi yang panjang dan berkembang secara lambat (Kemenkes RI, 2013). Kasus PTM terus mengalami peningkatan setiap tahun. World Health Organization (WHO) menyatakan pada tahun 2012 sebesar $68 \%$ atau 38 juta orang meninggal dunia disebabkan oleh PTM, dengan $80 \%$ kematian tersebut terjadi di negara miskin dan berkembang. Tahun 2015 PTM meningkat menjadi $70 \%$ atau 56,4 juta kematian di seluruh dunia (WHO, 2015).

Berdasarkan Riskesdas tahun 2013 beberapa PTM di Indonesia mengalami kecenderungan peningkatan prevalensi seperti diabetes mellitus, hipertensi dan stroke dari tahun 2007 ke tahun 2013. Tahun 2014 penyakit stroke, PJK, dan diabetes melitus menjadi penyebab kematian tertinggi di Indonesia (Kemenkes RI, 2017). Peningkatan prevalensi PTM setiap tahun memunculkan transisi epidemiologi di Indonesia. Transisi epidemiologi adalah keadaan yang ditandai dengan perubahan mortalitas dan morbiditas yang disebabkan oleh penyakit menular menjadi penyakit tidak menular. Empat jenis PTM utama menurut WHO adalah penyakit kardiovaskular (penyakit jantung koroner, stroke), kanker, penyakit pernapasan kronis, dan diabetes (Kemenkes RI, 2013). Upaya yang dapat dilakukan untuk mencegah dan menekan kejadian PTM adalah melalui pengendalian faktor risiko seperti obesitas, hipertensi, peningkatan kadar glukosa darah, dan kolesterol total darah (Kemenkes RI, 2016). Sindrom metabolik memiliki hubungan dengan peningkatan risiko penyakit kardiovaskular dan diabetes melitus tipe 2 (Kaur, 2014). Sindrom metabolik yang terdeteksi sejak dini dapat mencegah terjadinya penyakit metabolik dan komplikasi (Jafar, 2011).
Sindrom metabolik adalah kumpulan faktor risiko berbagai penyakit metabolik seperti Penyakit Jantung Koroner (PJK), stroke, dan diabetes melitus tipe 2. Komponen utama sindrom metabolik berdasarkan International Diabetes Federation (IDF) tahun 2005 adalah obesitas sentral, dislipidemia (trigliserida tinggi, kolesterol HDL rendah), hipertensi, dan hiperglikemia. Seseorang dinyatakan mengalami sindrom metabolik apabila terdapat obesitas sentral dengan minimal 2 kriteria positif lainnya (IDF, 2006).

Data dari Riskesdas tahun 2013 menunjukkan proporsi komponen sindrom metabolik dengan kriteria IDF mengalami peningkatan seperti obesitas sentral 26,6\%, hipertensi 9,3\%, dan diabetes melitus 13,3\% (Kemenkes RI, 2013). Berdasarkan penelitian pada kelompok usia 25-65 tahun yang dilakukan oleh Sirait tahun 2014 menyatakan sebesar $18,7 \%$ mengalami sindrom metabolik. Berdasarkan berbagai penelitian tersebut dapat dilihat bahwa prevalensi sindrom metabolik cukup tinggi di dunia termasuk di Indonesia khususnya pada kelompok usia produktif (Sirait, 2014).

Penelitian dari International Labour Organization (ILO) menyatakan salah satu Penyakit Akibat Hubungan Kerja (PAHK) yang menyebabkan kematian pada pekerja adalah penyakit kardiovaskular yang salah satu faktor risikonya adalah sindrom metabolik. Menurut Kamso tahun 2011 penelitian pada kalangan eksekutif yang merupakan kelompok manajerial di Jakarta menunjukkan prevalensi sindrom metabolik sebesar 21,6\% dengan prevalensi komponen tertinggi yaitu obesitas sentral sebesar 22,1\%. Penelitian lain pada pekerja perusahaan di Jakarta menunjukkan sebesar $21,58 \%$ pekerja mengalami sindrom metabolik dengan komponen terbanyak adalah obesitas sentral (Zahtamal, et al., 2014). Sindrom metabolik yang tinggi pada pekerja 
dikaitkan dengan faktor risiko seperti aktifitas fisik yang rendah, tingkat stres yang tinggi, asupan makanan yang tinggi karbohidrat dan lemak, serta rendahnya perhatian perusahaan terhadap kesehatan dan kebugaran para pekerja (Zahtamal, et, al., 2014). Sindrom metabolik menjadi
epidemik diseluruh dunia karena
meningkatnya prevalensi obesitas dan perilaku sedentari (Kassi, 2014). WHO menyatakan perilaku sedentari terjadi pada $23 \%$ penduduk dunia dan $15 \%$ di Asia pada usia dewasa (WHO, 2011). Proporsi perilaku sedentari lebih dari sama dengan 6 jam perhari pada usia lebih dari sama dengan 10 tahun di Indonesia cukup tinggi yaitu sebesar 26,1\% dan Provinsi Jawa Timur masuk dalam lima besar proporsi tertinggi yaitu 33,9\%. Menurut Kamso tahun 2011 perilaku sedentari yang tinggi, aktivitas fisik yang kurang memadai, dan pola makan yang cenderung tinggi karbohidrat dan lemak berisiko untuk menderita penyakit kardiovaskular pada usia muda (Kamso, 2011).

Sedentari pada pekerja dapat disebabkan oleh beberapa hal, diantaranya adalah jenis pekerjaan, hobi atau kesenangan, fasilitas yang mendukung perilaku sedenteri serta kurang berolahraga (Fadila, 2016). Selain itu, ketersediaan akses merupakan pendukung kegiatan sedentari. Kegiatan sedentari terdapat pada perilaku duduk yang terjadi dalam berbagai domain yaitu, rekreasi, pekerjaan dan transportasi termasuk bekerja/bermain di komputer, mengendarai mobil, dan menonton televisi (Raynor, et al., 2011).

Prevalensi perilaku sedentari yang tinggi pada kelompok usia produktif diduga menjadi faktor risiko sindrom metabolik pada pekerja. Oleh karena itu, penting untuk mengetahui hubungan perilaku sedentari terhadap kejadian sindrom metabolik agar dapat dijadikan dasar untuk mencegah kejadian sindrom metabolik.

\section{METODE PENELITIAN}

Penelitian ini merupakan jenis penelitian observasional dengan desain studi cross sectional. Sampel penelitian ini adalah pekerja yang melakukan Medical Check Up di Laboratorium Klinik Prima Medika Kota Surabaya pada bulan November - Desember 2017. Berdasarkan perhitungan besar sampel dengan rumus sampel Cross Sectional yang tidak diketahui jumlah populasinya menggunakan rumus Lemeshow (1997) maka didapat besar sampel yang digunakan pada penelitian ini adalah sebanyak 66 pekerja. Pengambilan sampel dilakukan dengan cara simple random sampling dari total 113 pekerja yang melakukan medical check up di Laboratorium Prima Medika Surabaya. Variabel bebas dalam penelitian ini adalah usia, jenis kelamin, dan perilaku sedentari. Variabel terikat dalam penelitian ini adalah sindrom metabolik yang berdasarkan kriteria IDF tahun 2005 ditandai dengan obesitas sentral ditambah minimal 2 kriteria positif dari 4 komponen lain yang terdiri dari dislipidemia (hipertrigliserida, kolesterol HDL rendah), hipertensi, dan hiperglikemia.

Data primer dalam penelitian ini diperoleh dari hasil wawancara menggunakan kuesioner yang diisi secara mandiri oleh responden dan pengukuran fisik secara langsung. Pengukuran perilaku sedentari menggunakan Kuesioner sedentary lifestyle Behavior (SBQ) yang telah diadaptasi dari penelitian Rosernberg Tahun 2010. SBQ terdiri dari 9 jenis kegiatan sedentari yang dilakukan dalam kegiatan sehari-hari seperti di rumah, di tempat kerja, dan di perjalanan atau transportasi (Rosernberg, 2010).

Pengukuran fisik dilakukan untuk mengukur tekanan darah dan lingkar perut. Data sekunder dalam penelitian ini diperoleh dari hasil pengamatan rekam medik berupa kadar trigliserida, kolesterol HDL, dan kadar glukosa darah puasa. Data yang telah diolah kemudian dilakukan 
analisis. Penelitian ini menggunakan dua macam analisis data, yaitu analisis univariabel untuk menghitung distribusi frekuensi pada setiap variabel yang menggambaran karakteristik responden berupa nilai maksimal dan minimal, mean, dan simpang baku dan analisis bivariabel dengan Chi-square digunakan untuk menganalisis hubungan variabel dependen dan independen. Analisis dilakukan untuk mengetahui ada/ tidak ada hubungan antar variabel yang ditentukan berdasarkan nilai p-value, dan mengetahui nilai Prevalence Risk (PR) yaitu ukuran yang didapat dari penelitian menggunakan desain Cross Sectional yang menunjukkan berapa kali (lebih besar/ lebih kecil) risiko untuk mengalami penyakit pada kelompok terpapar relatif dibandingkan kelompok tidak terpapar dengan $\alpha=5 \%$.

\section{HASIL}

\section{Distribusi Pekerja Berdasarkan Berbagai Karakteristik}

Distribusi usia pada pekerja yang melakukan Medical Check Up di Laboratorium Klinik Prima Medika Surabaya sebagian besar berada pada kelompok usia produktif lebih dari sama dengan 40 tahun yaitu sebanyak 48 orang $(72,7 \%)$. Usia terendah pekerja adalah 23 tahun dan tertinggi 58 tahun dengan ratarata usia yaitu 43 tahun. Menurut Kemenkes usia rerata tersebut tergolong pada usia dewasa akhir yaitu 36-45 tahun (Kemenkes RI, 2015). Distribusi pekerja berdasarkan jenis kelamin menunjukkan sebagian besar pekerja memiliki jenis kelamin perempuan yaitu sebanyak 37 pekerja (56,1\%). Distribusi pekerja berdasarkan tingkat pendidikan sebagian besar memiliki tingkat pendidikan yang tinggi. Hal tersebut ditunjukkan dari sebagian besar pekerja yang merupakan lulusan perguruan tinggi yaitu $86,4 \%$.

Distribusi pekerja berdasarkan jenis pekerjaannya menunjukkan sebagian besar pekerja merupakan pegawai baik pegawai negeri ataupun pegawai swasta yaitu sebesar $71,2 \%$ atau 47 pekerja. Berdasarkan lama bekerja, sebagian besar pekerja telah bekerja lebih dari 10 tahun yaitu sebanyak 51 pekerja $(77,3 \%)$ denganrata-rata lama bekerja selama 18,27 tahun.

Variabel perilaku sedentari per hari dikelompokkan berdasarkan besar risiko pada kejadian sindrom metabolik. Distribusi pekerja berdasarkan perilaku sedentari menunjukkan sebagian besar pekerja melakukan perilaku sedentari lebih dari sama dengan 6 jam per hari yaitu sebanyak 39 pekerja (59,1\%). Rentang waktu sedentari yang dilakukan oleh pekerja adalah 1 sampai dengan 23 jam per hari dengan rata - rata 9,11 jam per hari. Nilai ini menunjukkan perilaku sedentari yang tinggi pada pekerja. Berdasarkan jenis kegiatan sedentari, sebagian besar kegiatan sedentari dilakukan di tempat kerja atau saat melakukan pekerjaan didepan komputer yaitu sebesar 36,5\% dari total keseluruhan waktu sedentari per hari. Hal ini menunjukkan faktor tingginya perilaku sedentari pada pekerja yang disebabkan kegiatan atau pekerjaan di tempat kerja.

\section{Distribusi komponen Sindrom Metabolik pada Pekerja}

Variabel obesitas sentral memiliki perbedaan kriteria pada laki-laki dan perempuan berdasarkan kriteria IDF tahun 2005. Hasil pengukuran lingkar perut pada pekerja yang melakukan Medical Check Up menunjukkan sebanyak 48 pekerja (72,7\%) memiliki lingkar perut berlebih atau obesitas sentral. Rentang lingkar perut terkecil pada laki - laki adalah $63 \mathrm{~cm}$ dan terbesar $110 \mathrm{~cm}$ dengan rata - rata lingkar perut pada pekerja laki - laki adalah 92,31 $\mathrm{cm}$. Pada perempuan lingkar perut terkecil adalah $61 \mathrm{~cm}$ dan terbesar $106 \mathrm{~cm}$ dengan rata-rata $88,29 \mathrm{~cm}$. 
Tabel 1. Distribusi Pekerja yang Melakukan Medical Check Up di Laboratorium Prima Medika Surabaya pada Bulan November - Desember 2017 Berdasarkan Berbagai Karakteristik

\begin{tabular}{|c|c|c|c|c|c|}
\hline Karakteristik & Kelompok & Jumlah & $(\%)$ & $\overline{\mathbf{x}}$ & SD \\
\hline \multicolumn{6}{|l|}{ Usia } \\
\hline & $<40$ tahun & 18 & 27,3 & 43 & 8,04 \\
\hline & $\geq 40$ tahun & 48 & 72,7 & & \\
\hline \multicolumn{6}{|l|}{ Jenis Kelamin } \\
\hline & Laki-laki & 29 & 43,9 & & \\
\hline & Perempuan & 37 & 56,1 & & \\
\hline \multicolumn{6}{|l|}{ Pendidikan } \\
\hline & $\mathrm{SD}$ & 1 & 1,5 & & \\
\hline & SMP & 0 & 0,0 & & \\
\hline & SMA & 8 & 12,1 & & \\
\hline & PT & 57 & 86,4 & & \\
\hline \multicolumn{6}{|l|}{ Pekerjaan } \\
\hline & Buruh & 4 & 6,1 & & \\
\hline & Pegawai & 47 & 71,2 & & \\
\hline & Petani & 1 & 1,5 & & \\
\hline & Wiraswasta & 14 & 21,1 & & \\
\hline \multicolumn{6}{|l|}{ Lama Bekerja } \\
\hline & $<10$ tahun & 15 & 22,7 & 18,27 & 9,35 \\
\hline & $\geq 10$ tahun & 51 & 77,3 & & \\
\hline \multicolumn{4}{|l|}{ Sedentari /hari } & 9,11 & 4,29 \\
\hline & $\geq 6 \mathrm{Jam}$ & 39 & 59,1 & & \\
\hline
\end{tabular}

Tabel 2. Distribusi Komponen Sindrom Metabolik pada Pekerja yang Melakukan Medical Check Up di Laboratorium Prima Medika Surabaya pada Bulan November Desember 2017

\begin{tabular}{|c|c|c|c|c|c|c|}
\hline \multirow{2}{*}{$\begin{array}{l}\text { Komponen } \\
\text { Sindrom } \\
\text { Metabolik }\end{array}$} & \multicolumn{3}{|c|}{$\mathrm{Ya}$} & Tidak & \multirow[t]{2}{*}{$\overline{\mathrm{x}}$} & \multirow[t]{2}{*}{$\mathrm{SD}$} \\
\hline & Jumlah & $\begin{array}{l}\text { Persentase } \\
(\%)\end{array}$ & Jumlah & $\begin{array}{l}\text { Persentase } \\
(\%)\end{array}$ & & \\
\hline Obesitas sentral & 48 & 72,7 & 18 & 27,3 & $\begin{array}{l}\text { L: } 92,31 \\
\text { P: } 88,29\end{array}$ & $\begin{array}{l}\text { L: } 9,9 \\
\text { P: } 10,8\end{array}$ \\
\hline Hipertrigliserida & 37 & 56,1 & 29 & 43,9 & 190 & 89,64 \\
\hline $\begin{array}{l}\text { Kadar HDL } \\
\text { rendah }\end{array}$ & 34 & 51,5 & 32 & 48,5 & $\begin{array}{l}\text { L: } 41,41 \\
\text { P: } 46,21\end{array}$ & $\begin{array}{l}\text { L: } 9,2 \\
\text { P: } 9,7\end{array}$ \\
\hline Hipertensi & 45 & 68,2 & 21 & 31,8 & $118 / 79$ & $13,37 / 10,48$ \\
\hline Hiperglikemia & 47 & 71,2 & 19 & 28,8 & 95,36 & 33,70 \\
\hline $\begin{array}{l}\text { Status Sindrom } \\
\text { Metabolik }\end{array}$ & 29 & 43,9 & 37 & 56,1 & & \\
\hline
\end{tabular}


Gambar 1. Distribusi Komponen Sindrom Metabolik Berdasarkan Status Sindrom Metabolik Pada Pekerja yang Melakukan Medical Check Up di Laboratorium Prima Medika Surabaya pada Bulan November - Desember 2017

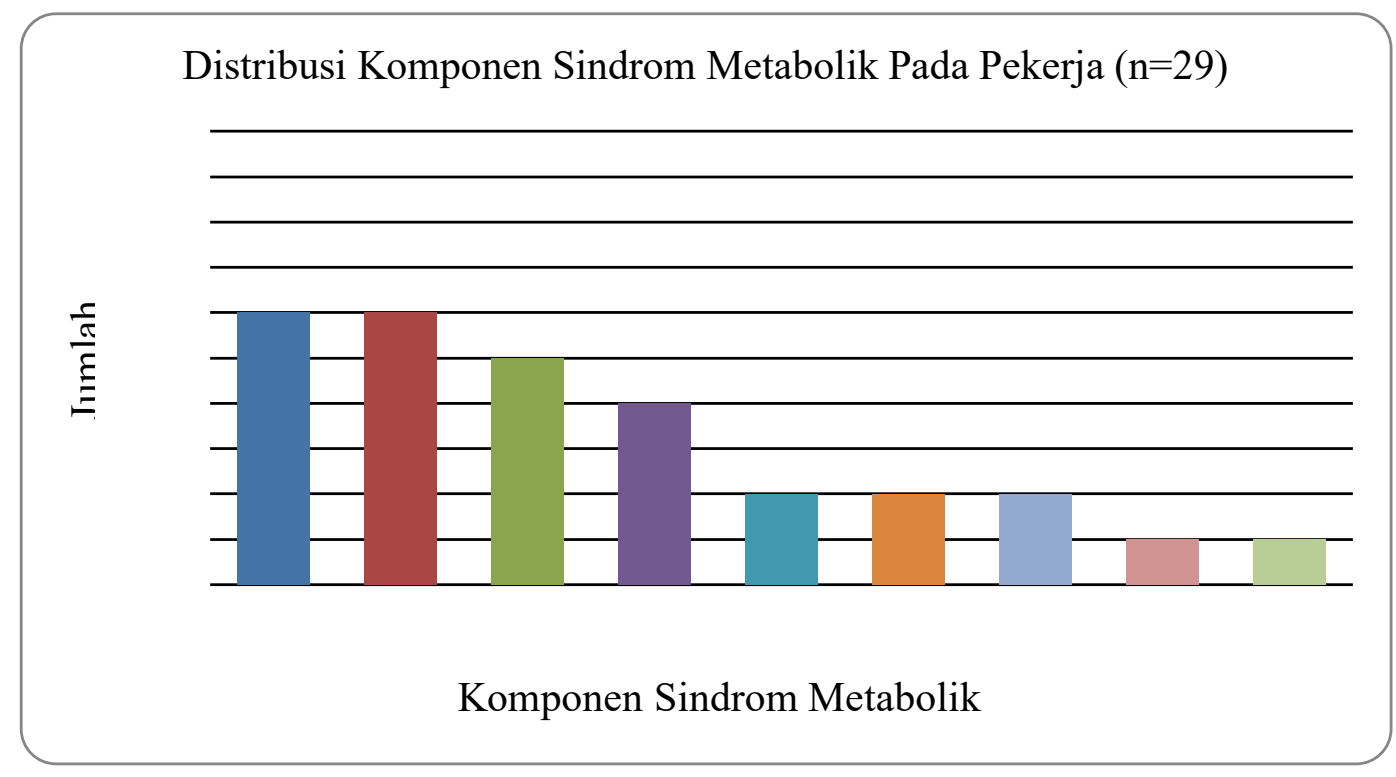

Keterangan :

$\mathrm{A}=$ Obesitas sentral + Hipertrigliserida + HDL rendah + Hipertensi + Hiperglikemia

$\mathrm{B}=$ Obesitas sentral + Hipertrigliserida + Hipertensi

$\mathrm{C}=$ Obesitas sentral + Hipertrigliserida + Hiperglikemia

$\mathrm{D}=$ Obesitas sentral + HDL rendah + Hipertensi + Hiperglikemia

$\mathrm{E}=$ Obesitas sentral + Hipertrigliserida + Hipertensi + Hiperglikemia

$\mathrm{F}=$ Obesitas sentral + Hipertrigliserida + HDL rendah + Hipertensi

$\mathrm{G}=$ Obesitas sentral + Hipertrigliserida + HDL rendah

$\mathrm{H}=$ Obesitas sentral + HDL rendah + Hiperglikemia

$\mathrm{I}=$ Obesitas sentral + Hipertrigliserida + HDL rendah + Hiperglikemia

Berdasarkan kriteria IDF tahun 2005 sebagian besar pekerja memiliki kadar trigliserida tinggi (lebih dari sama dengan $150 \mathrm{mg} / \mathrm{dL}$ ) atau hipertrigliserida yaitu sebanyak 37 pekerja $(56,1 \%)$. Rentang kadar trigliserida terendah pada pekerja adalah $69 \mathrm{mg} / \mathrm{dL}$ dan tertinggi 410 $\mathrm{mg} / \mathrm{dL}$ dengan rata-rata kadar trigliserida pada pekerja adalah $190 \mathrm{mg} / \mathrm{dL}$.

Berdasarkan Tabel 2 Sebanyak 34 pekerja $(51,5 \%)$ memiliki kadar kolesterol HDL yang rendah (laki-laki $=$ kurang dari $40 \mathrm{mg} / \mathrm{dL}$, Perempuan = kurang dari 50 $\mathrm{mg} / \mathrm{dL})$. Sebanyak 32 pekerja $(48,5 \%)$ lainnya memiliki kadar kolesterol HDL normal. Rentang kadar kolesterol HDL terendah pada laki-laki adalah $27 \mathrm{mg} / \mathrm{dL}$ dan tertinggi $67 \mathrm{mg} / \mathrm{dL}$ dengan rata - rata
41,41 mg/dL. Sedangkan, pada perempuan kadar kolesterol HDL terendah adalah 31 $\mathrm{mg} / \mathrm{dL}$ dan tertinggi $67 \mathrm{md} / \mathrm{dL}$ dengan ratarata $46,21 \mathrm{mg} / \mathrm{dL}$.

Berdasarkan kriteria IDF tahun 2005 sebanyak 45 pekerja $(68,2 \%)$ memiliki tekanan darah yang tinggi yaitu lebih dari sama dengan 130/85 $\mathrm{mmHg}$ atau hipertensi. Rentang tekanan darah terendah pada pekerja adalah 90/60 $\mathrm{mmHg}$ dan tertinggi $170 / 110 \mathrm{mmHg}$ dengan rata - rata tekanan darah pada pekerja adalah 118/79 $\mathrm{mmHg}$.

Pada Tabel 2 dapat diketahui berdasarkan kriteria IDF tahu 2005 sebanyak 47 pekerja $(71,2 \%)$ memiliki kadar glukosa darah puasa lebih dari sama dengan $100 \mathrm{mg} / \mathrm{dL}$ atau hiperglikemia. 
Rentang kadar glukosa darah puasa terendah pada pekerja adalah $60 \mathrm{mg} / \mathrm{dL}$ dan tertinggi $240 \mathrm{mg} / \mathrm{dL}$ dengan rata - rata kadar glukosa darah adalah 95, $36 \mathrm{mg} / \mathrm{dL}$.

\section{Distribusi Status Sindrom Metabolik pada Pekerja}

Status sindrom metabolik berdasarkan kriteria yang ditetapkan IDF 2005 menyatakan sindrom metabolik apabila memiliki obesitas sentral ditambah minimal 2 kriteria positif dari 4 komponen lain yaitu hipertrigliserida, kolesterol HDL rendah, hipertensi, dan hiperglikemia. Berdasarkan Tabel 2 Pekerja yang mengalami sindrom metabolik sebanyak 29 pekerja (43,9\%). Nilai ini juga menunjukkan besar prevalensi sindrom metabolik pada pekerja yang melakukan MCU di Laboratorium Prima Medika Surabaya.

Berdasarkan Gambar 1 Proporsi komponen sindrom metabolik terbanyak pada pekerja adalah yang mengalami kelima kriteria sindrom metabolik dan gabungan dari obesitas sentral, hipertrigliserida, dan hipertensi yaitu masing-masing sebanyak 6 orang. Hal ini menunjukkan hipertrigliserida dan hipertensi merupakan komponen sindrom metabolik yang banyak terjadi pada pekerja selain obesitas sentral.

\section{Hubungan Usia dengan Sindrom Metabolik pada Pekerja}

Hubungan usia dengan sindrom metabolik pada Tabel 3 menunjukkan sindrom metabolik lebih banyak terjadi pada kelompok pekerja yang berusia lebih dari sama dengan 40 tahun yaitu sebanyak 25 pekerja $(52,1 \%)$. Berdasarkan hasil uji statistik chi-square menujukkan usia dengan kategori lebih dari sama dengan 40 tahun dan kurang dari 40 tahun tidak berhubungan dengan sindrom metabolik pada pekerja. Hal ini dibuktikan dengan hasil uji statistik dengan $p$-value sebesar 0.058 ( $p$ lebih dari $\alpha$ ). Namun, berdasarkan nilai $P R=3.804$, dapat diketahui besar risiko seseorang yang memiliki usia lebih dari sama dengan 40 tahun terhadap sindrom metabolik adalah 3.804 kali dibandingkan dengan usia kurang dari 40 tahun.

\section{Hubungan Jenis Kelamin dengan Sindrom Metabolik pada Pekerja}

Hubungan jenis kelamin dengan
sindrom metabolik pada pekerja
menunjukkan bahwa pekerja laki-laki
memiliki proporsi lebih tinggi mengalami
sindrom metabolik dibanding pekerja
perempuan dengan selisih yang tidak jauh
berbeda.

Hubungan jenis kelamin dengan sindrom metabolik pada pekerja menunjukkan bahwa pekerja laki-laki memiliki proporsi lebih tinggi mengalami sindrom metabolik dibanding pekerja berbeda.

Tabel 3. Hubungan Usia, Jenis Kelamin, dan Perilaku Sedentari dengan Sindrom Metabolik pada Pekerja yang Melakukan Medical Check Up di Laboratorium Klinik Prima Medika Surabaya Bulan November - Desember 2017

\begin{tabular}{|c|c|c|c|c|c|c|c|c|}
\hline \multirow{3}{*}{ Karakteristik } & \multicolumn{4}{|c|}{ Sindrom Metabolik } & \multirow[b]{3}{*}{$\mathrm{n}$} & \multirow{3}{*}{$\begin{array}{l}\text { Total } \\
\%\end{array}$} & \multirow{3}{*}{$\begin{array}{l}p- \\
\text { value }\end{array}$} & \multirow[t]{3}{*}{ PR } \\
\hline & \multicolumn{2}{|c|}{$\mathrm{Ya}$} & \multicolumn{2}{|c|}{ Tidak } & & & & \\
\hline & $\mathrm{N}$ & $\%$ & $\mathrm{n}$ & $\%$ & & & & \\
\hline Usia & & & & & & & 0.058 & 3.804 \\
\hline$\geq 40$ tahun & 25 & 52,1 & 23 & 47,9 & 48 & 100,0 & & \\
\hline$<40$ tahun & 4 & 22,2 & 14 & 77,8 & 18 & 100,0 & & \\
\hline Jenis Kelamin & & & & & & & 0.168 & 0.44 \\
\hline Laki-laki & 21 & 56,8 & 16 & 43,2 & 37 & 100,0 & & \\
\hline Perempuan & 16 & 55,2 & 13 & 44,8 & 29 & 100,0 & & \\
\hline Perilaku Sedentari & & & & & & & 0.000 & 16.000 \\
\hline $\mathrm{Ya}(\geq 6 \mathrm{Jam})$ & 26 & 66,7 & 13 & 33,3 & 39 & 100,0 & & \\
\hline Tidak $(<6$ Jam $)$ & 3 & 11,1 & 24 & 88,9 & 27 & 100,0 & & \\
\hline
\end{tabular}


Hasil uji statistik chi-square menujukkan jenis kelamin tidak berhubungan dengan sindrom metabolik pada pekerja. Hal ini dibuktikan dengan hasil uji statistik dengan $p$-value sebesar 0.168 ( $p$ lebih dari $\alpha$ ). Berdasarkan nilai $P R=0.44$, dapat diketahui besar risiko laki-laki terhadap sindrom metabolik adalah 0.44 kali dibandingkan dengan perempuan.

\section{Hubungan Perilaku Sedentari dengan Sindrom Metabolik pada Pekerja}

Hubungan perilaku sedentari dengan status sindrom metabolik pada pekerja menunjukkan sebagian besar pekerja yang mengalami sindrom metabolik memiliki perilaku sedentari lebih dari sama dengan 6 jam per hari yaitu sebanyak 26 pekerja $(66,7 \%)$. Hasil uji statistik chi-square menujukkan perilaku sedentari dengan kategori elbih dari sama dengan 6 jam per hari dan kurang dari 6 jam per hari berhubungan dengan sindrom metabolik pada pekerja yang dibuktikan dengan dengan nilai $p$-value sebesar 0.000 ( $p$ kurang dari $\alpha$ ). Selain itu, berdasarkan nilai $P R=16$. $000(\mathrm{CI} 95 \%=4,056-$ 63,124) dapat diketahui besar risiko seseorang yang memiliki perilaku sedentari lebih besar sama dengan 6 jam per hari terhadap sindrom metabolik adalah 16 kali dibanding seseorang dengan perilaku sedentari kurang dari 6 jam per hari.

\section{PEMBAHASAN}

\section{Distribusi Pekerja Berdasarkan Usia}

Hasil penelitian diketahui bahwa sebagian besar pekerja berada pada kelompok usia lebih dari sama dengan 40 tahun dengan rata-rata usia pekerja 43 tahun. Menurut Mahendra, et al., pada usia tersebut kemampuan tubuh melakukan sekresi insulin dan kemampuan kerja reseptor insulin akan menurun sehingga berisiko mengalami sindrom metabolik.
Penelitian lain menyatakan prevalensi sindrom metabolik mengalami peningkatan pada usia di atas 40 tahun (Zahtamal, et al., 2014).

\section{Distribusi Pekerja Berdasarkan Jenis Kelamin}

Hasil penelitian pada Tabel 1 diketahui bahwa distribusi pekerja yang melakukan MCU di Laboratorium Klinik Prima Medika Surabaya sebagian besar adalah perempuan. Sindrom metabolik pada perempuan berkaitan dengan faktor usia. Pada perempuan di atas usia 50 tahun terjadi peningkatan obesitas sentral yang umum dijumpai setelah kehamilan dan saat menopause dikarenakan adanya peningkatan jaringan adiposa. (Misnadiarly, 2007).

\section{Distribusi Pekerja Berdasarkan Tingkat Pendidikan}

Berdasarkan hasil penelitian sebagian besar pekerja memiliki tingkat pendidikan yang tinggi. Usaha meningkatkan kesehatan masyarakat salah satunya adalah pendidikan. Peningkatan pendidikan yang baik akan meningkatkan orang berpengetahuan yang baik pula. Namun, berdasarkan penelitian dari Sholechah tahun 2014 tingkat pendidikan tidak mempunyai pengaruh terhadap kejadian sindrom metabolik (Sholechah, 2014). Artinya kelompok dengan pendidikan tinggi dan rendah mempunyai peluang yang sama untuk mengalami sindrom metabolik.

\section{Distribusi Pekerja Berdasarkan Jenis Pekerjaan}

Berdasarkan hasil penelitian diketahui bahwa sebagian besar pekerja merupakan pegawai baik negeri maupun swasta. Menurut data dari Lembaga Ilmu Pengetahuan Indonesia tahun 2005 kelompok pekerja pegawai/ karyawan masuk ke dalam kelompok pekerjaan dengan aktivitas fisik ringan yang sebagian 
besar kegiatannya dilakukan dengan posisi duduk dengan sedikit berdiri atau berpindah. Aktivitas fisik yang ringan menyebabkan pengeluaran energi yang sedikit atau rendah. Selain itu, tingginya aktivitas sedentari pada kelompok tersebut menimbulkan kerentanan terhadap penyakit sindrom metabolik (Fadila, 2016).

\section{Distribusi Pekerja Berdasarkan Perilaku Sedentari}

Berdasarkan hasil penelitian diketahui sebagian besar pekerja memiliki perilaku sedentari yang tinggi lebih dari sama dengan 6 jam $(59,1 \%)$. Data tersebut sesuai dengan hasil penelitian bahwa sebagian besar pekerja mempunyai perilaku sedentari dalam kategori tinggi yaitu sebanyak 48,8\% (Harymbawa, 2016). Penelitian serupa juga menghasilkan sebanyak $60 \%$ pegawai mempunyai perilaku sedentari (Istiqomah, 2010)

\section{Distribusi Komponen Sindrom Metabolik pada Pekerja}

Berdasarkan hasil penelitian diketahui sebagian besar pekerja yang melakukan MCU di Laboratorium Klinik Prima Medika Surabaya memiliki lingkar perut berlebih. Hasil penelitian ini sejalan dengan penelitian sindrom metabolik pada pekerja di perusahaan yang menyatakan sebagian besar pekerja mengalami obesitas sentral (Zahtamal, et al., 2014).

Berdasarkan hasil penelitian pada sebagian besar pekerja yang melakukan MCU di Laboratorium Klinik Prima Medika Surabaya memiliki kadar trigliserida di atas normal atau hipertrigliserida. Hasil ini serupa dengan penelitian yang dilakukan oleh Zahtamal, et al (2014) yang menyatakan sebagian besar pekerja mengalami gejala dislipidemia yaitu peningkatan kadar trigliserida. Penelitian lain oleh Sholecah pada tahun 2014 juga menyatakan terdapat peningkatan kadar trigliserida pada pekerja di pabrik.
Berdasarkan hasil penelitian pada sebagian besar pekerja memiliki kadar kolesterol HDL di bawah normal. Hasil ini sesuai dengan penelitian yang dilakukan oleh Zahtamal, et al., tahun 2014 yang menyatakan sebagian besar pekerja memiliki kadar kolesterol HDL yang rendah. Kadar kolesterol HDL yang rendah dapat disebabkan beberapa faktor. Hasil penelitian diperoleh faktor tersebut diantaranya: berat badan, IMT dan lingkat perut yang berhubungan dengan rasio trigliserida dan kolesterol HDL (Sutadarma, 2011).

Berdasarkan hasil penelitian menyatakan sebagian besar pekerja mengalami hipertensi. Hasil tersebut juga didapat pada penelitian Zahtamal, et al., tahun 2014 yang dilakukan pada pekerja di Jakarta. Hipertensi pada pekerja dapat disebabkan berbagai faktor. Hipertensi pada pekerja berhubungan dengan stres kerja, pola makan di tempat kerja serta kebiasaan olahraga. Penelitian lain menyatakan sebagian besar pegawai mengalami hipertensi yang disebabkan faktor aktivitas fisik yang rendah dan status gizi (Paruntu, 2015). Asupan makanan berlebih mengakibatkan obesitas yang merupakan faktor risiko penyakit lain seperti diabetes melitus, kardiovaskular, dan hipertensi.

Berdasarkan hasil penelitian pada tabel 3 sebagian besar pekerja memiliki kadar glukosa darah puasa lebih dari sama dengan $100 \mathrm{mg} / \mathrm{dL}$ atau risiko hiperglikemia menurut kriteria IDF 2005. Hasil ini sejalan dengan hasil penelitian oleh Harymbawa (2016) yang menyatakan pada sebagian besar pekerja konveksi mempunyai kadar glukosa darah dalam kategori hiperglikemia (Harybawa, 2016). Zahtamal, et al., tahun 2014 menyatakan hasil yang sama pada kelompok pekerja di Jakarta.

\section{Distribusi Status Sindrom Metabolik pada Pekerja}

Berdasarkan hasil penelitian pada Tabel 3 didapatkan sebanyak 29 atau 
$43,9 \%$ pekerja mengalami sindrom metabolik. Nilai tersebut juga menunjukkan prevalensi sindrom metabolik pada pekerja yang melakukan MCU di Laboratorium Prima Medika Surabaya pada Bulan November-Desember 2017. Hasil ini meningkat dibanding dengan penelitian dari Zahtamal, et al., tahun 2014, prevalensi kasus sindrom metabolik untuk periode tersebut adalah 21,58\%. Prevalensi sindrom metabolik dari sumber/data dan hasil penelitian lain salah satunya IDF tahun 2011 menyebutkan bahwa prevalensi sindrom metabolik dunia adalah 20-25\%. Hal ini menunjukkan adanya peningkatan prevalensi sindrom metabolik pada pekerja.

Sindrom metabolik yang meningkat pada pekerja penting mendapat perhatian. Sindrom metabolik yang tidak tertangani dapat meningkatkan risiko penyakit kardiovaskular dan diabetes melitus dan menjadi komplikasi (Jafar, 2011). Wulandari (2013) menyatakan seseorang yang mengalami sindrom metabolik lebih risiko terjadi komplikasi mikrovaskular. Sindrom metabolik juga berhubungan dengan kejadian stroke (Chrisna, et al., 2016). Selain itu, sindrom metabolik yang tinggi pada pekerja secara tidak langsung akan berpengaruh terhadap sosioekonomi individu, perusahaan, dan negara karena meningkatnya beban biaya kesehatan (Kassie, 2014).

\section{Hubungan Usia dengan Sindrom Metabolik pada Pekerja}

Berdasarkan hasil penelitian diketahui tidak terdapat hubungan antara usia dengan sindrom metabolik sehingga antara kelompok usia kurang dari 40 tahun maupun lebih dari sama dengan 40 tahun bukan merupakan faktor risiko terjadinya sindrom metabolik pada pekerja. Data tersebut sesuai dengan penelitian yang dilakukan oleh Sholecah tahun 2014 yang menyatakan usia tidak berhubungan signifikan dengan kejadian sindrom metabolik pada pekerja. Hal tersebut dapat disebabkan usia produktif mempunyai beban pekerjaan yang tinggi, aktivitas fisik yang kurang memadai, dan pola makan yang cenderung tinggi kadar karbohidrat dan lemak sehingga berisiko untuk menderita berbagai penyakit metabolik pada usia yang relatif masih muda (Kamso, 2011).

\section{Hubungan Jenis Kelamin dengan Sindrom Metabolik pada Pekerja}

Berdasarkan hasil penelitian diketahui tidak terdapat hubungan antara jenis kelamin dengan sindrom metabolik pada pekerja. Baik laki- laki maupun perempuan mempunyai peluang yang sama untuk mengalami sindrom metabolik. Hasil penelitian ini berbeda dengan Kamso (2011) dan Zahtamal, et al., (2014) yang menyatakan sindrom metabolik lebih banyak terjadi pada pekerja laki-laki. Namun, hasil penelitian ini sejalan dengan penelitian oleh Sihombing tahun 2015 yang memperlihatkan jenis kelamin tidak mempunyai hubungan yang bermakna (Sihombing, 2015). Hasil ini juga sejalan dengan penelitian kohor dari National Health and Nutrition Examination Survey (NHANES) tahun 2003-2006 yang melaporkan tidak ada perbedaaan yang signifikan proporsi sindrom metabolik antara laki laki dan perempuan (Ervin, 2009).

\section{Hubungan Perilaku Sedentari dengan Sindrom Metabolik pada Pekerja}

Berdasarkan hasil penelitian
diketahui terdapat hubungan antara
perilaku sedentari dengan sindrom
metabolik pada pekerja yang melakukan
MCU di Laboratorium Klinik Prima
Medika Surabaya yang dibuktikan dengan
nilai p kurang dari $\alpha$. Hasil ini sesuai
dengan penelitian Kamso (2011) yang
menyatakan bahwa karakteristik
demografi, gaya hidup, jenis kelamin, dan
aktivitas sedentari berhubungan dengan
sindrom metabolik. Hasil ini juga
mendukung konsep tentang hubungan
aktivitas fisik dengan kejadian sindrom


metabolik. Aktivitas fisik yang kurang (sedentary lifestyle) berhubungan dengan kejadian sindrom metabolik. Beberapa faktor perilaku pekerja diketahui juga berkontribusi terhadap timbulnya sindrom metabolik. Faktor tersebut antara lain faktor pekerjaan yang memicu pekerja cenderung untuk berperilaku sedenter, pola makan tidak sehat, perilaku merokok, stres, dan lain-lain.( Zahtamal, et al., 2014). Gaya hidup sedentari ditambah dengan pola makan buruk yang tinggi lemak dan karbohidrat (fast food) dan tidak diimbangi serat (sayuran dan buah) dalam jumlah yang cukup, menyebabkan penumpukan lemak dengan gejala kelebihan berat badan (obesitas), terutama di bagian perut (Alam, 2007). Obesitas sentral menjadi faktor risiko yang berkaitan erat dengan beberapa penyakit kronis (Kemenkes RI, 2015).

Menurut Syawal tahun 2008 obesitas sentral menjadi faktor risiko penyakit jantung koroner karena menyebabkan kerentanan terhadap diabetes melitus, hipertensi, dislipidemia, dan pembengkakan jantung (Syawal, 2008). Obesitas sentral juga menjadi komponen utama yang memicu resistensi insulin yang menjadi awal mula terjadinya sindrom metabolik (IDF, 2006).

Perilaku sedentari pada pekerja yang terbukti berhubungan dengan kejadian sindrom metabolik perlu mendapat perhatian. Mengurangi perilaku sedentari dan meningkatkan perbaikan gizi atau kesehatan penting dalam upaya mencegah angka kesakitan akibat penyakit tidak menular atau penyakit degeneratif, menurunkan angka absensi serta meningkatkan produktivitas kerja.

\section{SIMPULAN}

Berdasarkan hasil penelitian dan pembahasan tentang hubungan perilaku sedentari dengan sindrom metabolik pada pekerja yang melakukan MCU di Laboratorium Klinik Prima Medika Surabaya Bulan November- Desember
2017 dapat disimpulkan prevalensi sindrom metabolik pada pekerja adalah sebesar 43,9 \%. Karakteristik sebagian besar pekerja berjenis kelamin perempuan, berada pada kelompok usia lebih dari sama dengan 40 tahun, memiliki tingkat pendidikan yang tinggi, bekerja sebagai pegawai, bekerja lebih dari sama dengan 10 tahun, dan memiliki perilaku sedentari yang tinggi, usia dan jenis kelamin tidak berhubungan dengan sindrom metabolik pada pekerja, sedangkan perilaku sedentari berhubungan dengan sindrom metabolik pada pekerja.

\section{DAFTAR PUSTAKA}

Chrisna, F F., Martini S. 2016. Hubungan Antara Sindroma Metabolik Dengan Kejadian Stroke . Departemen Epidemiologi FKM UA. Jurnal Berkala Epidemiologi, Vol. 4, No. 1 Januari 2016: 25-36

Ervin RB. 2009. Prevalence of metabolic syndrome among adults 20 years of age and over, by sex, age, race and ethnicity, and body mass index: United States 2003-2006. Natl Health Stat Report. 2009;5:1-7

Fadila, Ila. 2016. Relasi Perilaku Sedentari, Gizi Lebih, dan Produktivitas Kerja Masyarakat Perkotaan.

Harymbawa, I Wayan Aditya. 2016. Hubungan Sedentary Lifestyle dengan Kadar Glukosa Darah pada Orang Dewasa Pekerja Konveksi Di Kelurahan Genuk Ungaran Barat. Sekolah Tinggi Ilmu Kesehatan

International Diabetes Federation. The IDF consensus worldwide definition of the metabolic syndrome. 2006.

Istiqamah, Nurul., Sirajuddin, Saifuddin., Indriasari, Rahayu. 2014. Hubungan Pola Hidup Sedentarian Dengan Kejadian Obesitas Sentral Pada Pegawai Pemerintahan Di 
Kantor Bupati Kabupaten Jeneponto.

Jafar, Nurhaedar. 2011. Sindrom Metabolik. Universitas Hasanuddin. Makassar

Kamso, Sudijanto., Purwantyastuti., Lubis, Dharmayati Utoyo., Ratna Juwita, Yul Kurnia Robbi. 2011. Prevalensi dan Determinan Sindrom Metabolik pada Kelompok Eksekutif di Jakarta dan Sekitarnya.

Kaur J 2014. A comprehensive review on metabolic syndrome. BMC Public Health.

Kassi E, Pervanidou P, Kaltsas G, Chrousos G. 2011. Metabolic syndrome: definitions and controversies. BMC Public Health.

Kemkes RI. 2017. Warta Kesmas Edisi 012017. Germas Aksi Nyata Untuk Hidup Sehat.

Kemkes Republik Indonesia. 2013. Riset Kesehatan Dasar 2013. Badan Penelitian dan Pengembangan Kesehatan Kementerian Kesehatan RI

Mahendra, B., Tobing, Ade., Krisnatuti, Diah., Alting, Boy Z. A. 2008. Care yourself diabetes melitus. Jakarta: Penebar Plus.

Misnadiarly. 2007. Obesitas Sebagai Faktor Risiko Beberapa Penyakit. Jakarta: Pustaka Obor.

Paruntu,Olga Lieke., Rumagit, Fred A., Kures, Griche S. 2015. Hubungan Aktivitas Fisik, Status Gizi dan Hipertensi pada Pegawai Di Wilayah Kecamatan Tomohon Utara.Poltekkes Manado. Manado

Rahmadani, Anissa., Indrisari, rahayu., Yustini.2014. Hubungan Aktivitas Sedentari dengan Kejadian Overweight pada Remaja di SMA Katolik Cendrawasih Makassar. Universitas

Raynor, H. A., Bond, D. S., Freedson, P. S. \& Sisson, S. B. 2011. Sedentary Behaviors, Weight, And Health And Disease Risks. Journal of Obesity.
Rosenberg, Dori E., Norman, Gregory J., Wagner, Nicole., Patrick, Kevin., Calfas, Karen J., Sallis, James F.2010. Reliability and Validity of Sedentary Behaviour Questionnaire (SBQ) for Adults.Journal of Physical Activity and Health.

Solechah, siti aisyah., Briawan,dodik., Kustiyah, lilik. 2014. Proporsi Dan Faktor Risiko Sindrom Metabolik Pada Pekerja Wanita Di Pabrik GarmenDi Kota Bogor(Proportion And Risk FactorsOf Metabolic Syndrome Among Female Workers In Textile Factory In Bogor City).

Sihombing M, Tjandrarini, Dwi Hapsari. 2015. Faktor Risiko Sindrom Metabolik Pada Orang Dewasa Di Kota Bogor (Risk Factors Metabolic Syndrome Among In Bogor) Adults. Pusat Teknologi Terapan Kesehatan dan Epidemiologi Klinik, Badan Litbangkes, Kemenkes RI. Jakarta

Sirait, A.M., Sulistiowati, E. 2014. Sindrom Metabolik Pada Orang Dewasa Di Kota Bogor, 20112012. Media Penelitian dan Pengembangan.

Sutadarma, IGW., Purnawati S., Ruma., IMW. 2011. Hubungan Stres Kerja, status Gizi, dan Sindrom Metabolik pada Karyawan LakiLaki Dewasa. Universitas Udayana. Bali

WHO. 2017. 10 facts on physical activity.

Wulandari, M Y, Isfandiari M A. 2013. Kaitan Sindroma Metabolik Dan Gaya Hidup Dengan Gejala Komplikasi Mikrovaskuler. The Relationship Between Metabolic Syndrome And Life Symptoms Style With Microvascular Complications. FKM UA. Jurnal Berkala Epidemiologi, Vol. 1, No. 2 September 2013: 224-233

Zahtamal., Wasilah Rochmah., Yayi Suryo Prabandari., Lientje K. Setyawati. 2014. Prevalensi Sindrom 
Lailiyah Yusna Yusfita, Hubungan Perilaku Sedentari Dengan... 155

Metabolik Pada Pekerja

Masyarakat Nasional Vol 9 No2.

Perusahaan. Jurnal Kesehatan 